\title{
Perbandingan NaCl 3\% dan Manitol pada Cedera Kepala Akibat Trauma di Ruang Rawat Intensif Anak
}

\author{
Rina Amalia C. Saragih, Syilvia Jiero, Johannes H. Saing, Munar Lubis \\ Departemen Ilmu Kesehatan Anak Fakultas Kedokteran Universitas Sumatera Utara/ RSUP H. Adam \\ Malik, Medan
}

\begin{abstract}
Latar belakang. Manitol dan $\mathrm{NaCL}$ 3\% merupakan agen hiperosmolar yang direkomendasikan pada pasien anak dengan cedera kepala akibat trauma. Beberapa penulis memberikan argumen bahwa larutan salin hipertonis lebih efektif, tetapi belum ada konsensus berkaitan dengan indikasi, konsentrasi, dan cara pemberian yang terbaik.

Tujuan. Membandingkan pemakaian manitol dan $\mathrm{NaCl} 3 \%$ pada anak dengan cedera kepala akibat trauma yang dirawat di ruang rawat intensif dalam hal lama rawatan, mortalitas, dan gangguan elektrolit.

Metode. Penelitian retrospektif dilakukan dengan pengumpulan data rekam medis pasien traumatic brain injury (TBI) yang dirawat di ruang rawat intensif anak RSUP H. Adam Malik selama kurun waktu Juni 2012 sampai dengan Mei 2013. Data dibagi atas dua kelompok, yaitu pasien yang mendapatkan manitol dan $\mathrm{NaCl} 3 \%$ sebagai agen hiperosmolar. Analisis statistik dilakukan dengan Mann Whitney U-test, chisquare, dan fisher exact test.

Hasil. Subjek 47 orang pasien TBI, 29 di antaranya mendapatkan manitol dan 18 mendapat $\mathrm{NaCl}$ 3\%. Perbandingan antara kelompok manitol dan $\mathrm{NaCl} 3 \%$ tidak menunjukkan perbedaan yang bermakna secara statistik dalam hal lama rawatan $[(5,79 \pm 4,37$ hari $)$ vs $(6,00 \pm 4,20$ hari $) ; \mathrm{p}=0,733]$, mortalitas $(44,44 \%$ vs $20,69 \% ; p=0,083)$, dan gangguan elektrolit $(37,93 \%$ vs $33,33 \%)$.

Kesimpulan. Tidak ada perbedaan dalam hal lama rawatan, mortalitas dan gangguan elektrolit dengan penggunaan manitol dan $\mathrm{NaCl} 3 \%$ sebagai agen hiperosmolar pada pasien cedera kepala akibat trauma. Dibutuhkan penelitian lebih lanjut dengan metode prospektif dan jumlah sampel yang lebih besar.

Sari Pediatri 2015;16(6):375-8.
\end{abstract}

Kata kunci: manitol, $\mathrm{NaCl} 3 \%$, cedera kepala akibat trauma

\footnotetext{
Alamat korespondensi:

Dr. Rina Amalia C. Saragih, MKed (Ped), Sp.A. Staf Divisi Gawat Darurat Pediatri, Departemen Ilmu Kesehatan Anak FK Universitas Sumatera Utara/ RSUP. H. Adam Malik Medan. Jalan Bunga Lau No. 17, Medan 20136, Telp (061) 8361721, Fax (061) 8361721. E-mail: rina.amalia.srgh@gmail.com
}

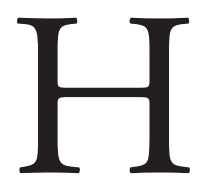

ipertensi intrakranial yang terjadi setelah cedera neurologis sering berkaitan dengan luaran yang buruk. ${ }^{1}$ Manitol dan $\mathrm{NaCl}$ $3 \%$ merupakan agen hiperosmolar yang direkomendasikan pada pasien anak dengan cedera kepala akibat trauma. ${ }^{2}$ Beberapa penulis 
memberikan argumen bahwa salin hipertonis lebih efektif, ${ }^{1,3,4}$ tetapi belum ada konsensus berkaitan dengan indikasi, konsentrasi, dan cara pemberian yang terbaik. ${ }^{1}$ Gangguan elektrolit merupakan salah satu efek samping yang perlu dipantau dalam pemakaian manitol dan $\mathrm{NaCl} 3 \% .^{5,6}$ Tujuan dari penelitian ini adalah membandingkan pemakaian manitol dan $\mathrm{NaCl}$ $3 \%$ pada anak dengan cedera kepala akibat trauma yang dirawat di ruang rawat intensif, dalam hal lama rawatan, mortalitas, dan gangguan elektrolit.

\section{Metode}

Penelitian retrospektif dilakukan dengan pengumpulan data rekam medis pasien traumatic brain injury (TBI) yang dirawat di ruang rawat intensif anak/ Pediatric Intensive Care Unit (PICU) RSUP H. Adam Malik Medan selama kurun waktu Juni 2012 sampai Mei 2013. Diagnosis TBI ditegakkan dengan adanya riwayat trauma kepala, gangguan neurologis, dan kelainan pada computed tomography scan (CT Scan) kepala. statistik jika $\mathrm{p}<0,05$.

\section{Hasil}

Didapati 47 pasien TBI dan seluruhnya diikutsertakan dalam penelitian. Dari keseluruhan pasien tersebut, 29 di antaranya mendapatkan manitol dan $18 \mathrm{NaCl} 3 \%$ sebagai agen hiperosmolar (Tabel 1).

Pada lama rawatan tidak didapatkan perbedaan bermakna $(\mathrm{p}=0,733)$ antara kelompok manitol $(5,8 \pm 4,37)$ hari dan $\mathrm{NaCl} 3 \%(6,0 \pm 4,20)$ hari. Dijumpai mortalitas lebih tinggi pada kelompok $\mathrm{NaCl} 3 \%$ dibandingkan manitol (8:6) orang, tetapi perbedaan tersebut tidak bermakna secara statistik $(\mathrm{p}=0,083)$.

Pada gangguan elektrolit tidak didapatkan perbedaan yang bermakna antara kelompok manitol dengan $\mathrm{NaCl} 3 \%(\mathrm{p}=0,750)$. Terdapat 11 pasien yang mendapatkan manitol mengalami gangguan elektrolit, sedangkan pada kelompok $\mathrm{NaCl} 3 \%$ didapati 6 pasien yang mengalami gangguan elektrolit. Jenis gangguan elektrolit yang didapati tertera pada Tabel 2 .

Tabel 1. Data dasar kelompok manitol dan $\mathrm{NaCl} 3 \%$

\begin{tabular}{|c|c|c|c|}
\hline Parameter & Manitol & $\mathrm{NaCl} 3 \%$ & $\mathrm{p}$ \\
\hline Usia (tahun, rerata, SD) & $12,1(5,57)$ & $10,5(6,49)$ & 0,319 \\
\hline \multicolumn{4}{|l|}{ Jenis kelamin $(n, \%)$} \\
\hline Laki-laki & $24(82,8)$ & $15(83,3)$ & 0,642 \\
\hline Perempuan & $5(17,2)$ & $3(16,7)$ & \\
\hline Skor PELOD* (rerata, SD) & $11,9(11,32)$ & $11,7(10,55)$ & 0,595 \\
\hline
\end{tabular}

"Pediatric Logistic Organ Dysfunction

Kriteria inklusi adalah pasien usia 1 bulan sampai 18 tahun dengan diagnosis TBI yang dirawat di ruang rawat intensif anak dan diberikan manitol atau $\mathrm{NaCl}$ $3 \%$. Pasien dengan lama rawatan kurang dari 12 jam dieksklusikan dari penelitian. Data dibagi atas dua kelompok, yaitu pasien yang mendapatkan manitol (dosis 0,25-1 gr $/ \mathrm{kgBB} / \mathrm{kali}$, diberikan tiap 4-6 jam) dan $\mathrm{NaCl} 3 \%$ (dosis $10 \mathrm{~mL} / \mathrm{kgBB} / \mathrm{hr}$, dibagi atas dua dosis) sebagai agen hiperosmolar. Dilakukan pencatatan usia, jenis kelamin, skor PELOD (pediatric logistic organ dysfunction), gangguan elektrolit selama rawatan PICU, lama rawatan, dan mortalitas.

Data diolah dengan perangkat lunak statistik. Mann Whitney U-test, chi-square, dan Fisher exact test digunakan untuk membandingkan antara kelompok manitol dan $\mathrm{NaCl}$ 3\%. Dinyatakan bermakna secara
Tabel 2. Gangguan elektrolit pada kelompok manitol dan $\mathrm{NaCl} 3 \%$

\begin{tabular}{lcc}
\hline Gangguan elektrolit & Manitol (n,\%) & $\mathrm{NaCl} 3 \%(\mathrm{n}, \%)$ \\
\hline Hiponatremia & $21(72,4)$ & $11(61,1)$ \\
Hipernatremia & $1(3,5)$ & $1(5,6)$ \\
Hipokalemia & $4(13,8)$ & $1(5,6)$ \\
Hiperkalemia & $0(0)$ & $1(5,6)$ \\
Hipokalsemia & $10(34,5)$ & $6(33,3)$ \\
\hline
\end{tabular}

\section{Pembahasan}

Terdapat rekomendasi level II yang menyebutkan bahwa larutan salin hipertonis sebaiknya dipertimbangkan untuk tata laksana pasien anak dengan TBI berat 
disertai dengan hipertensi intrakranial. ${ }^{7}$ Belum ada konsensus tentang dosis yang digunakan. Suatu meta analisis menunjukkan pemakaian yang bervariasi antara infus kontinu dan bolus. ${ }^{1}$ Suatu penelitian menunjukkan bahwa pemakaian salin hipertonis meningkat sementara pemakaian manitol menurun. ${ }^{8}$ Dalam penelitian ini, pemilihan manitol atau $\mathrm{NaCl}$ 3\% didasarkan pada keputusan klinis ahli neurologi anak dan pediatric intensivist. Dosis $\mathrm{NaCl} 3 \%$ yang digunakan saat penelitian berlangsung adalah $10 \mathrm{~mL} /$ $\mathrm{kgBB} / \mathrm{hr}$ dan dibagi atas dua dosis.

Suatu systematic review dari uji klinis acak terkontrol tentang pemakaian manitol pada TBI akut melaporkan bahwa manitol dapat memberikan efek mortalitas yang lebih buruk jika dibandingkan dengan salin hipertonis. Namun, perbandingan review tersebut hanya mendapati satu penelitian, itupun terlalu kecil untuk mendapatkan kesimpulan yang sahih. ${ }^{9}$ Meta analisis yang membandingkan salin hipertonis dengan manitol dalam penanganan peningkatan tekanan intrakranial mendapatkan bahwa salin hipertonis lebih efektif dibandingkan manitol. ${ }^{3}$ Pada penelitian ini didapatkan lama rawatan yang tidak berbeda antara kelompok manitol dan $\mathrm{NaCl} 3 \%$. Mortalitas kelompok $\mathrm{NaCl} 3 \%$ lebih tinggi daripada mortalitas kelompok manitol, tetapi perbedaan tersebut tidak bermakna secara statistik. Banyak faktor yang dapat memengaruhi mortalitas, di antaranya tingkat keparahan penyakit dan lama pasien mendapatkan terapi medikamentosa maupun tindakan surgical setelah kejadian trauma. Tingkat keparahan penyakit saat awal rawatan tidak berbeda antara kedua kelompok. Hal tersebut ditunjukkan dari skor PELOD yang tidak berbeda bermakna secara statistik antara kelompok manitol dengan kelompok $\mathrm{NaCl} 3 \%$.

Kadar elektrolit perlu dipantau selama pemakaian agen hiperosmolar. Rozet $\mathrm{dkk}^{5}$ mendapatkan bahwa manitol menyebabkan penurunan kadar natrium dalam darah yang cepat dan peningkatan kalium dengan berjalannya waktu, sedangkan salin hipertonis menyebabkan peningkatan segera kadar natrium (berlanjut selama 6 jam) dan penurunan segera kadar kalium yang transien. Penelitian lain yang dilakukan terhadap anak dengan peningkatan tekanan intrakranial yang dirawat di ruang rawat intensif, ditunjukkan adanya peningkatan kadar natrium dan klorida pada kelompok yang mendapatkan salin hipertonis 3\%, tetapi masih dalam rentang kadar yang bisa diterima. ${ }^{10}$ Pada penelitian ini hipernatremia hanya didapati pada satu pasien untuk masing-masing kelompok. Gangguan elektrolit yang terbanyak dijumpai adalah hiponatremia. Secara keseluruhan tidak didapatkan perbedaan gangguan elektrolit antara kelompok manitol dengan $\mathrm{NaCl} 3 \%$. Banyak faktor yang dapat memengaruhi kadar elektrolit pada pasien yang dirawat di PICU, di antaranya asupan elektrolit, penyakit penyerta, dan fungsi ginjal yang tidak dianalisis dalam penelitian ini.

Keterbatasan penelitian ini adalah besar sampel yang relatif kecil dan data dikumpulkan secara retrospektif. Dibutuhkan penelitian lebih lanjut dengan metode prospektif dan besar sampel yang lebih banyak.

\section{Kesimpulan}

Tidak ada perbedaan lama rawatan, mortalitas, dan gangguan elektrolit dengan penggunaan manitol dan $\mathrm{NaCl} 3 \%$ sebagai agen hiperosmolar pada pasien cedera kepala akibat trauma. Dibutuhkan penelitian lebih lanjut dengan metode prospektif dan besar sampel yang lebih besar.

\section{Ucapan Terimakasih}

Terima kasih kepada Prof. dr. H. Chairul Yoel, Sp.A(K), dr. Gema Nazri Yanni, MKed(Ped), Sp.A dan seluruh staf divisi PGD PICU FK USU - RSUP. H. Adam Malik Medan serta dr. Yazid Dimyati, Sp.A(K).

\section{Daftar pustaka}

1. Mortazavi MM, Romeo AK, Deep A. Hypertonic saline for treating raised intracranial pressure: literature review with meta-analysis. J Neurosurg 2012;116:210-21.

2. Lerner JT, Giza CC. Traumatic brain injury in children. Dalam: Swaiman KF, Ashwal S, Ferriero DM, Schor NF, penyunting. Swaiman's pediatric neurology principles and practice. Edisi ke-5. Volume 1. Edinburgh: Elsevier Saunders; 2012.h.1087-125.

3. Kamel H, Navi BB, Nakagawa K, Hemphill III JC, Ko NU. Hypertonic saline versus mannitol for the treatment of elevated intracranial pressure: a meta-analysis of randomized clinical trials. Crit Care Med 2011;39:554-9.

4. Marko NF. Hypertonic saline, not mannitol, should be 
considered gold-standard medical therapy for intracranial hypertension. Crit Care 2012;6:113.

5. Rozet I, Tontisirin N, Muangman S. Effect of equiosmolar solutions of mannitol versus hypertonic saline on intraoperative brain relaxation and electrolyte balance. Anesthesiology 2007;107:697-704.

6. Rockswold GL, Solid CA, Paredes-Andrade E, Rockswold SB, Jancik JT, Quickel RR. Hypertonic saline and its effect on intracranial pressure, cerebral perfusion pressure, and brain tissue oxygen. Neurosurgery 2009;65:1035-42.

7. Kochanek PM, Carney N, Adelsen PD. Guidelines for the acute medical management of severe traumatic brain injury in infants, children, and adolescents-second edition. Pediatr Crit Care Med 2012;13 Suppl 1:S3641.

8. Bennett TD, Statler KD, Korgenski EK, Bratton SL. Osmolar therapy in pediatric traumatic brain injury. Crit Care Med 2012;40:208-15.

9. Wakai A, Roberts IG, Schierhout G. Mannitol for acute traumatic brain injury. Cochrane Database of Systematic Reviews [Internet] 2007. Diakses pada 10 Mei 2014. Didapat dari: http://www.thecochranelibrary.com/userfiles/ ccoch/file/CD001049.pdf

10. Upadhyay P, Tripathi VN, Singh RP, Sachan RP. Role of hypertonic saline and mannitol in the management of raised intracranial pressure in children: A randomized comparative study. J Pediatr Neurosci 2010;5:18-21. 